\title{
Okul Öncesi Öğretmenlerinin Fen Eğitimi Süreçleri Üzerine Görüşlerinin İncelenmesi ${ }^{1}$ Investigation of Preschool Teachers' Views on Science Education Processes
}

\author{
Ahmet SIMSAR \\ Kilis 7 Aralık Üniversitesi, Muallim Rlfat Eğitim Fakültesi, Okul Öncesi Eğitimi ABD \\ e-posta:ahmetsimsarr@gmail.com

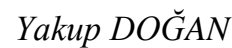 \\ Kilis 7 Aralık Üniversitesi, Muallim Rlfat Ĕ̆itim Fakültesi, Okul Öncesi Eğitimi ABD \\ e-posta:yakupdogan06@gmail.com
}

Atıf: Simsar, A. ve Doğan, Y. (2019). Okul öncesi öğretmenlerinin fen eğitimi süreçleri üzerine görüşlerinin incelenmesi. E-Kafkas Eğitim Araştırmaları Dergisi, 6(2), 19-32.

Gönderi Tarihi:10.07.2019

Kabul Edilme Tarihi: 27-09-2019

DOI: $10.30900 /$ kafkasegt.590361

\section{Özet}

Bu çalışmada, okul öncesi öğretmenlerinin fen eğitimi olgusuna ilişkin görüşlerinin derinlemesine incelenmesi amaçlanmıştır. Araştırmanın çalışma grubunu Kilis il merkezinde bulunan Milli Eğitim Bakanlığına bağlı anaokullarında ve ana sınıflarında görev yapmakta olan 70 okul öncesi öğretmeni oluşturmaktadır. Araştırmanın verileri, nitel metodolojide sıklıkla kullanılan görüşme tekniği kullanılarak toplanmıştır. Görüşmeler sırasında öğretmenlerin verdikleri cevaplar yazılı olarak kaydedilmiş, daha sonra bilgisayar ortamına aktarılarak nitel bir veri seti oluşturulmuştur. Verilerin analizinde içerik analizi yöntemi kullanılmıştır. Okul öncesi öğretmenlerin fen eğitimi ile ilgili görüşlerinin tanımlanmasında elde edilen kodlara ilişkin frekans ve yüzdelik dağılımları hesaplanarak tablolar şeklinde verilmiştir. Araştırma sonucunda, öğretmenlerin görüşlerine göre fen eğitiminin okul öncesi dönemde başlaması gerektiği, üniversitede verilen Fen Eğitimi dersinin yetersiz olduğu, fen eğitimine ilişkin kaynak kitapların yetersiz olduğu, öğretmenlerin fen etkinliklerini planlama ve uygulamada kendilerini yeterli olarak tanımladıkları belirlenmiştir. Öğretmenlerin çoğunluğunun sınıfta düzenli olarak fen etkinlikleri yaptıkları, ancak fen merkezlerinde bulunan materyallerin yetersiz olduğu, öğretmenlerin ihtiyaç duydukları fen materyallerini geliştirebildikleri, fen etkinlikleri için en fazla deney, soru cevap, grup çalışmaları, drama, gezi gözlem ve proje gibi yöntem ve teknikleri kullandıkları belirlenmiştir. Öğretmenlerin fen etkinlikleri değerlendirme sürecinde daha çok çocukların öğrenmesine, sonuç çıkartabilmelerine, aktif katılımlarına dikkat ettikleri bulunmuştur.

Anahtar Sözcükler: Fen eğitimi, okul öncesi ĕgitim, okul öncesi ögretmenleri.

\begin{abstract}
In this study, it was aimed to investigate in depth the opinions of preschool teachers related to science education processes. The study group consists of 70 preschool teachers who work in kindergartens and nursery class affiliated to the Ministry of National Education in the city center of Kilis province, Turkey. The data were collected by using an interview technique which is frequently used in qualitative methodology. The content analysis method was used for data analysis. Teachers' answers were transferred to a computer and a qualitative data set was created. The recorded data were examined one by one and coded by researchers. Frequency and percentage distributions of the codes obtained in the definition of preschool teachers' views about science education were calculated and given in the tables. As a result of the research, it was determined that science education should start in preschool period according to teachers' opinions, Science Education course given in university was insufficient, resource books related to science education were insufficient and teachers defined themselves as sufficient in planning and implementing science activities. It was determined that the majority of the teachers regularly carried out science activities in the classroom, but the materials in the science centers were insufficient, the teachers could develop the science materials they needed, and the methods and techniques such as experiment, question, and answer, group works, drama, trip observation, and project were the most used for science activities. It was found that teachers pay more attention to learning, educing and active participation of children in the evaluation of science activities.
\end{abstract}

Keywords: Science education, preschool education, preschool teachers.

\footnotetext{
${ }^{1} \mathrm{Bu}$ çalışmanın bir kısmı, 27-30 Haziran 2018 tarihlerinde Azerbaycan Devlet Pedagoji Üniversitesi'nde düzenlenen IV. Uluslararası Türk Kültür Coğrafyasında Eğitim ve Sosyal Bilimler Sempozyumu'nda sözlü bildiri olarak sunulmuştur.
} 


\section{GíRiş}

Çocuğun gelişiminin en hızlı olduğu dönem olan okul öncesi dönem, çocuğun gelişimi ve eğitimi açısından önemli olduğu kadar bireyin yetişkin dönemde ulaşacağı kapasitenin gelişimi açısından da oldukça önemlidir. Okul öncesi dönemde edinilen bilgilerin daha kalıcı olduğu ve sonraki yıllarda kazanılacak bilgilere temel oluşturduğu bilinmektedir. Okul öncesi dönem, çocuğun bilgi ve becerilerinin temellerinin atıldığ ve olaylar hakkındaki sorularına cevap aramak için gözlemlerde bulunduğu ve ilk fen kavramlarının oluştuğu dönemdir (Alisinanoğlu, Özbey ve Kahveci, 2015; Güler ve Bıkmaz, 2002). Fen eğitimi okul öncesi dönemdeki eğitimin bir parçasıdır. Çevresiyle etkileşime geçen çocuk, olgulara ve gözlemlediği olaylara cevap bulmaya çalışacak ve zihninde fene ilişkin bilişsel ve duyuşsal alana yönelik yapılanmalar oluşturmaya başlayacak ve bu süreç yaşamı boyunca devam edecektir (Yaşar, 1993).

Eğer çocuklar okul öncesi dönemde fen etkinliklerine ilişkin başarılı deneyimler ve olumlu hisler kazanırlarsa ileriki yıllarda fenle ilgili deneyimlerinde başarılı olacaklardır. Bu da çocukların fene yönelik olumlu tutum kazanmalarını, çocuklar yaşamları boyunca fene ilgi göstermelerini ve fen öğrenmekten zevk almalarını sağlayacaktır. Ancak çocuklar fen ile ilgili etkinliklerde öğretmenleri tarafindan iyi desteklenmezse ve olumsuz deneyimler yaşarlarsa hayatlarının geri kalan kısmında çoğunlukla fenle ilgili çalışmalardan uzak duracaklardır (Simpson ve Oliver, 1990). Dolayısıyla öğretmenler okul öncesi dönemde fen eğitimindeki rolleri ile çocukların gelecekte fenle ilgili akademik yaşantılarında etkin ve önemli bir rol üstlenmektedirler. Bu süreçte öğretmenlerin fene yönelik tutumları, çocuklara etkili bir fen eğitimi için önemli bir unsur olarak görülmektedir (Koballa ve Crawley, 1985; McDevitt ve Heikkinen, 1993). Bu nedenle sistemli bir fen eğitiminin okul öncesi dönemde başlamasının önemli bir gereklilik olduğu tartı̧ılmaz bir gerçeklik olarak kabul edilmektedir. Bu eğitim sürecinin sağlıklı ilerleyebilmesi için de fen eğitiminin doğru ve çocukların gelişimlerine uygun bir şekilde verilmesi büyük önem taşır. Dolayısıyla okul öncesi dönem fen eğitiminde öğretmenler, çocukların gelecek dönemlerindeki fenle ilgili akademik yaşantılarında etkin ve önemli bir rol üstlenmektedirler. Bu açıdan en önemli görev okul öncesi öğretmenlere düşmektedir. Öğretmenler, fen eğitiminin önemini bilmeli ve buna uygun etkinlikler hazırlayarak çocukların bu yöndeki gelişimlerini desteklemelidir.

Fen eğitimi; çocuğun karşılaştığı nesnelerin, olayların ve bunların ilişkilerini gözlemlemesi (Demiriz ve Ulutaş, 2001), incelemesi, araştırması ve sonuçlara varması olarak tanımlanabilir. Okul öncesinde fen eğitimi, çocukların merak duygularını geliştirerek araştırma yapmasına firsat tanıyan, çevrelerindeki olayları ve varlıkları gözlemleyerek farklılıkları ve benzerlikleri keşfetmesi için zemin hazırlayan ve çocuklar için günlük yaşamlarında gerekli olan becerileri kazandıran bir eğitimdir. Okul öncesi dönemde verilecek bu fen eğitimi ile araştırıcı, sorgulayıcı ve yaratıı düşünme becerileri gelişmiş, mantıklı düşünen bireyler yetiştirmek mümkün olabilir. Erken dönemdeki fen çalışmalarının çocuklara bir diğer katkısı da çocukların öğrendikleri bilgileri günlük yaşamda ne şekilde kullanabileceğine yol gösterici olmasıdır. Çocuklar fen eğitimi ile edindikleri bilgileri kullandıklarında çevreye nasıl uyum sağlayabildiklerini ve bilgilerin çevreyi korumalarında nasıl etkili olabildiğini bu çalışmalar sonucunda daha kolaylıkla yaşayarak görebilmektedirler (MEB, 2016).

Okul öncesi dönemde fen eğitiminin amacı, çocuğa doğaya ilişkin temel olgu ve olayların gerçekleşmesine dair temel bilgileri vermenin yanı sıra, onlara duyuşsal ve psiko-motor becerileri kazandırmak, kendisini ve çevresini anlamasına yardımcı olmaya çalışmaktır (Şahin, 1996).

Okul öncesi dönemdeki fen eğitimi, fene ilişkin temel bilgilerinin aktarılması şeklinde değil, çocuğun merakını giderecek yönde olmalıdır. Fen eğitiminde çocuğun araştırma, inceleme ve gözlem yapma becerilerini geliştirmesine, sağlam bilimsel temeller oluşturarak bilimsel düşünmeyi öğrenebilmesine fırsat verilmesi gerekmektedir. Okul öncesi öğretmeninin görevi sadece fen etkinliklerini planlamak ve konuyla ilgili materyaller sağlamakla sınırlı değildir. Öğretmenin görevi çocuklara bilgileri aktarmak değil, onları araştırmaya sevk etmek, etkinliklerle zenginleştirilmiş uygun ortam sağlamak (Aktaş-Arnas, 2002), neden sonuç ilişkisini kurmalarını yardımcı olmak ve onların temel bilimsel süreç becerilerinin gelişimlerini destekleyerek deneyimlerden çıkarımda bulunmalarına rehberlik etmektir (Bilaloğlu, 2014; Saçkes, Trundle, Bell ve O'Connell, 2011). Bu süreçte öğretmenlerin çocuklara doğru rehberlik edebilmeleri için fen eğitiminin önemini ve amacını iyi kavramaları, fen etkinliklerine çocukları katarak onları sürekli olarak aktif tutup öğrenmeyi daha ilginç ve etkili hale getirecek yöntem ve teknikler hakkında yeterli bilgiye sahip olmaları gerekmektedir (Alisinanoğlu vd., 2015; Demir ve Şahin, 2015). Bunların yanı sıra okul öncesi dönemde çocukların fene ilgilerinin arttırılması ve fen konusundaki tutumlarının olumlu yönde gelişimi için olumlu temellerin atılması konusunda öğretmenlere önemli sorumluluklar düşmektedir (Davies ve Howe, 2003).

Fenin okul öncesi dönemdeki önemi düşünüldüğünde okul öncesi öğretmenlerinin fenin içerisinde yer alan fizik, kimya, biyoloji, çevre gibi temel disiplinlere ilişkin genel bilgisinin yeterli olması da beklenmektedir (Kallery, 2004). Öğretmenlerin fene yönelik bilgileri, düşünceleri ve tutumları onların eğitimsel tecrübelerinden 
kaynaklanmaktadır. Fene ilişkin olumsuz düşüncelere ve tutumlara sahip olan öğretmenler, bu olumsuz tutumlarını çocuklara aktarmakta ve onların fen konularında eksik ve yanlış bilgilere sahip olmalarına da neden olmaktadırlar. Dolayısıyla çocuklar okul öncesi dönemde henüz fene karşı olumsuz tutum geliştirmemişken öğretmenlerinin bu tür tutumlarından olumsuz yönde etkilenmektedirler (Davies ve Howe, 2003). Türkiye'de okul öncesi ögretmenleri üniversite öğrenimleri esnasında zorunlu olarak "Fen Eğitimi”" dersini almaktadırlar. Bunun yanı sıra seçmeli olarak "Fen ve Doğa Etkinlikleri”, "Çevre Eğitimi”, "Okul Öncesi Dönemde Çevre Etkinlikleri” gibi dersler de alabilmektedirler. Bu dersler sayesinde okul öncesi öğretmenlerinin fen ve çevrenin önemini anlamaları, fen ve çevre eğitimi konularından, etkinliklerinden ve öğretim yöntem-tekniklerinden haberdar olmaları ve fenle ilgili etkinlikleri planlama, hazırlama ve uygulama becerilerinin gelişimi amaçlanmaktadır. Bu amaçlardan hareketle okul öncesi öğretmenlerinin fen, doğa ve çevre konularında temel bilgilere sahip, fen eğitimini önemseyen, fene yönelik olumlu görüşlere ve tutumlara sahip, fenle ilgili etkinlikler hazırlama uygulama becerisine sahip, fenle ilgili materyaller geliştirebilen, fenle ilgili bilimsel kaynakları takip eden ve farklı öğretim yöntem ve tekniklerini doğru kullanabilen, etkinlikleri uygun tekniklerle değerlendirebilen kişiler olması beklenmektedir.

Okul öncesi dönem fen eğitimine ilişkin mevcut literatür kapsamlı olarak incelendiğinde yapılan araştırmaların fen eğitimini çoğunlukla öğretmen yeterliliği, materyal boyutu, etkinlik planlama ve uygulama, kavram öğretimi, kullanılan yöntem ve teknikler gibi değişik boyutlar altında inceledikleri göze çarpmaktadır. Literatürde fen eğitimi ile ilgili yapılan araştırmalara bakıldığında; okul öncesi öğretmenlerinin üniversitelerde fen eğitimine yönelik alınan dersleri yetersiz buldukları (Aslan, Şenel-Zor ve Tamkavas-Cicim, 2015), fen etkinliklerinin planlanması ve uygulanması aşamasında farklı yöntem ve tekniklerin kullanılmasına ilişkin sorunlar yaşadıkları, fen etkinliklerine fazla yer vermedikleri, fen eğitimi noktasında kendilerini yetersiz hissettikleri (Ayvac1, Devecioğlu ve Yiğit, 2002; Günay-Bilaloğlu, Aslan ve Aktaş-Arnas, 2008), araç-gereç eksikliğinden dolayı çocukların pasif olduğu fen etkinliklerine yer verdikleri (Çınar, 2013; Dağl1, 2014; Kıldan ve Pektaş, 2009), öğretmenlerin en fazla deney, drama gibi yöntemleri kullandıkları, diğer yöntemleri çok kullanmadıkları (Güven, Ahi, Tan ve Karabulut, 2013; Özbek, 2009; Şahin, 1996;), araç-gereç ve materyaller yetersiz olduğu için daha çok gezi ve gözlem temelli etkinlikler tercih ettikleri (Güler ve Bıkmaz, 2002) görülmektedir. Ayrıca öğretmenlerin yaptıkları etkinliklerde fen kavramlarına ilişkin kendi bilgi düzeylerini yeterli bulmadıkları (Cho, Kim ve Choi, 2003; Çamlıbel-Çakmak, 2012; Çınar, 2013; Kallery, 2004) ve bu bilgilerin çocuklara aktarılması noktasında yetersiz hissettikleri (Brenneman, 2011; Ekinci-Vural ve Hamurcu, 2008; Okur-Akçay, 2016) çeşitli çalışmalarda ortaya konmuştur. Bununla beraber ülkemizde okul öncesi fen eğitimine yönelik kapsamlı çalışmalar hızlı bir artış göstermektedir (Özen-Uyar ve Ormancı, 2016). Bu çalı̧̧mada elde edilecek sonuçların da okul öncesi öğretmenlerin fen eğitimini uygulama ve değerlendirme süreçlerinde nelere dikkat ettikleri ve bunlara yönelik olarak okul öncesi eğitimde yer alan paydaşlardan (milli eğitim, aileler, çocuklar, üniversiteler, vb.) beklentilerinin neler olduğu şeklinde literatüre katkı sağlayacağı düşünülmektedir. Tüm bu bilgiler ışığında bu çalışmada, okul öncesi fen eğitimine ilişkin olarak alanda aktif görev yapan okul öncesi öğretmenlerinin görüşlerinin bütünsel bir bakış açısıyla derinlemesine incelenmesi amaçlanmıştır.

\section{YÖNTEM}

\section{Araşturma Deseni}

$\mathrm{Bu}$ araştırma, okul öncesi öğretmenlerinin fen eğitimine ilişkin düşüncelerini inceleyen tarama çalışmasıdır. Tarama çalışmaları nitel araştırma türlerinden betimleyici bir araştırma modeli olup kişilerin bir konu hakkındaki görüşlerinin, ilgilerinin, becerilerinin olduğu şekliyle açıklamayı amaçlayan bir araştırma yaklaşımıdır (Büyüköztürk vd., 2017; Karasar, 2014). Tarama araştırmalarında araştırmacı, çalışma grubunda yer alan katılımcıların bir konu hakkındaki görüşlerini ve kaynağını betimlemeye çalışır.

\section{Çalışma Grubu}

Araştırmanın çalışma grubunu, 2017-2018 eğitim öğretim yılında Kilis İl Milli Eğitim müdürlüğüne bağlı farklı anaokulu ve ana sinıflarında görev yapan 70 (28 ana sınıfı ve 42 anaokulu) okul öncesi öğretmeni oluşturmaktadır. Çalışma grubu Kilis İl Milli Eğitim müdürlüğünde görev yapmakta olan tüm öğretmenlerden seçilmiştir. Bundan dolayı çalışma grubu amaçlı örneklem yöntemi ile belirlenmiş ve tüm evreni oluşturan 81 öğretmene ulaşılmıştır. Öğretmenlerin çoğunluğu 21-30 yaş grubunda (\%61.4) bir kısmı 31-40 yaş grubunda $(\% 27.1)$ ve çok az kısmı 41 yaş ve üstü grubunda (\%11.4) bulunmaktadır. Katılımcılar, kıdem durumlarına göre en fazla 6-10 yıllık (\%45.7), bir kısmının 1-5 yıl (\%41.4) ve çok az bir kısmının da 11-20 yıl ve üstü (\%12.9) iş deneyimine sahiptir. Katılımcıların çoğunluğu Okul Öncesi Öğretmenliği mezunu (\%61.4) bir kısmı AÖF-Okul Öncesi Öğretmenliği mezunu (\%30), çok az kısmı ise Kız Meslek Lisesi (\%2.9) ve Çocuk Gelişimi Eğitimi (\%5.7) mezunudur. 


\section{Veri Toplama Aracı}

Araştırmada veri toplama aracı olarak 16 adet açık uçlu sorudan oluşan bir soru havuzu oluşturulmuştur. Daha sonra bu soruların kapsam geçerliliğinin sağlanması için alanında uzman öğretim elemanlarına (bir okul öncesi, bir fen eğitimi, bir ölçme değerlendirme), anlaşılırlık ve dil geçerliliği için bir okul öncesi öğretmeni ve bir Türkçe eğitimi alanında çalışan öğretim elemanına gönderilmiştir. Uzman görüşleri doğrultusunda ilk kısmında demografik soruların ikinci kısmında ise fen eğitimi ile ilgili yapılandırılmış açık uçlu 9 sorunun bulunduğu bir görüşme formu oluşturulmuştur. Araştırmacılar tarafından il merkezindeki anaokulları ve ana sınıflarında görev yapan tüm öğretmenlere (81 kişi) ulaşılarak görüşme formundaki sorular yöneltilerek verdikleri cevaplar katılımcıların ses kaydı yapılmasına izin vermemelerinden dolayı yazılı olarak kayıt altına alınmıştır. Ancak 11 öğretmenin verdiği cevaplar eksik ve yetersiz olduğu için değerlendirmeye alınmamıştır. Görüşmeler okullarda gerçekleştirilmiş ve her görüşme yaklaşık 15 dakika sürmüştür.

\section{Verilerin Analizi}

Görüşmeler sırasında öğretmenlerin verdikleri cevaplar yazılı olarak kaydedilmiş, daha sonra bilgisayar ortamına aktarılmış ve nitel bir veri seti oluşturulmuştur. Görüşme yapılan öğretmenler yansızlı̆̆ göstermek amacıyla Ö1, Ö2, ... Ö70 şeklinde kodlanmıştır. Veriler içerik analizine tabi tutulduktan sonra öğretmenlerle ilgili demografik bilgilerin yüzde (\%) ve frekans (f) dağılımları hesaplanmıştır. Yapılan bu yüzde ve frekans dağılımlarıyla okul öncesi öğretmenlerinin okul öncesinde fen eğitimine ilişkin görüşleri daha detaylı ve derinlemesine ortaya konulmaya çalışılmıştır. Miles ve Huberman (1994) nitel çalışmalarda aynı verinin iki farklı araştırmacı tarafından kodlama yapılması durumunda çalışmada yer alan kodların ve temaların daha keskin ve geçerliği tamamlayacağını dile getirmiştir. Ayrıca araştırmacılar, üzerinde uzlaşılan kod sayısının toplam uzlaşılan ve uzlaşılamayan kod sayısına bölünerek kodlama yapan araştırmacılar arasındaki güvenirlik sağlanmış olacaktır. $\mathrm{Bu}$ oranın \%70 ve yüksek olması araştırmanın güvenirliliğini arttıracaktır (Miles ve Huberman, 1994). Bu çalışmada analizlerin geçerlik ve güvenirliğinin sağlanması için veriler araştırmacılar tarafından ayrı ayrı analiz edildikten sonra oluşturulan temalar ve kodların sayıları karşılaştırılmıştır. Miles ve Huberman'ın (1994) formülüne göre, araştırmacılar tarafından oluşturan temalar ve kodlardaki \%97'lik benzerlik çalışmada araştırmacılar tarafından güvenirliliği gösterirken, bu oranda benzerlik göstermeyen \%3 kodlar araştırmacılar tarafından tartışılmış ve son hali tablolar halinde verilmiştir.

\section{BULGULAR}

Okul öncesi öğretmenlerinin fen eğitimine ilişkin düşüncelerinin incelendiği bu çalışmada öncelikle öğretmenlere fen/çevre alanlarına yönelik bazı kişisel sorulmuş ve elde dilen bulgular aşağıda Tablo 1'de sunulmuştur.

Tablo 1.

Öğretmenlerin Fen/Çevre Alanlart ile İlgili Betimleyici Bilgileri

\begin{tabular}{|c|c|c|c|}
\hline & Kodlar & $\mathbf{f}$ & $\%$ \\
\hline \multirow{2}{*}{ Fen/Çevre Eğitimine Yönelik Ders Alma Durumu } & Aldım & 47 & 67.1 \\
\hline & Almadım & 23 & 32.9 \\
\hline \multirow{2}{*}{$\begin{array}{l}\text { Fen/Çevre Alanlarına Yönelik Yayın Aboneliği } \\
\text { Durumu }\end{array}$} & Evet & 1 & 1.4 \\
\hline & Hayır & 69 & 98.6 \\
\hline \multirow{2}{*}{$\begin{array}{l}\text { Fen/Çevre Alanlarına Yönelik Sivil Toplum } \\
\text { Kuruluşuna Üyelik Durumu }\end{array}$} & Evet & 5 & 7.1 \\
\hline & Hayır & 65 & 92.9 \\
\hline \multirow{3}{*}{$\begin{array}{l}\text { Fen/Çevre Alanlarına Yönelik Haber ve Bilgileri } \\
\text { Takip Etme Durumu }\end{array}$} & Her zaman takip ediyorum & 7 & 10.0 \\
\hline & Ara sira takip ediyorum & 59 & 84.3 \\
\hline & Hiç takip edemiyorum & 4 & 5.7 \\
\hline \multirow{3}{*}{$\begin{array}{l}\text { Fen/Çevre Alanlarına Yönelik Bilimsel } \\
\text { Etkinliklere (konferans, sempozyum, fuar vb.) } \\
\text { Katılma Durumu }\end{array}$} & Her zaman katılıyorum & 3 & 4.3 \\
\hline & Ara sira katıliyorum & 36 & 51.4 \\
\hline & Hiç katılamıyorum & 31 & 44.3 \\
\hline \multirow{3}{*}{$\begin{array}{l}\text { Fen/Çevre Alanlarına Yönelik Sportif Etkinliklere } \\
\text { (kamp, doğa yürüyüşü vb.) Katılma Durumu }\end{array}$} & Her zaman katılıyorum & 1 & 1.4 \\
\hline & Ara sira katıliyorum & 23 & 32.9 \\
\hline & Hiç katılamıyorum & 46 & 65.7 \\
\hline
\end{tabular}

Öğretmenlerin çoğunluğunun öğretmenlikten önceki öğrenimleri esnasında fen/çevre eğitimine yönelik ders aldıkları (\%67.1) ancak yaklaşık üçte birlik kısmının (\%32.9) bu konuda herhangi bir ders almadıkları belirlenmiştir. Öğretmenlerin tamamına yakının (\%98.6) fen/çevre alanlarına yönelik herhangi bir yayın aboneliği bulunmamaktadır. Öğretmenlerin çoğunluğu (\%92.9) fen/çevreye alanlarına yönelik sivil toplum kuruluşlarına üyelikleri bulunmamaktadır. Öğretmenlerin büyük çoğunluğu fen/çevre alanlarına yönelik haberleri ara sıra 
(\%84.3) takip etmektedir. Öğretmenlerin yarıdan fazlası (\%51.4) fen/çevreye alanlarına yönelik bilimsel etkinliklere (konferans, sempozyum, fuar vb.) ara sıra katılım gösterirken, yarıya yakın bir kısmı (\%44.3) ise hiç katılamamaktadır. Benzer şekilde öğretmenlerin çoğunluğu (\%65.7) fen/çevreye alanlarına yönelik sportif faaliyetlere hiç katılamamakta, az bir kısmı (\%32.9) ise ara sıra katılmaktadır.

Okul öncesi kurumlarında çalışan öğretmenlerin fen eğitimi olgusuna ilişkin görüşlerini derinlemesine ortaya çıkarmak amacıyla dokuz tane açık uçlu soru sorulmuştur. İlk olarak öğretmenlerin çocuklar için fen eğitiminin başlaması gereken döneme ilişkin görüşlerini ortaya çıkarmak amacıyla "Size göre çocuklar için fen eğitimin başlaması gereken dönem ne zaman olmalıdır? Açıklayınız?" sorusu sorulmuş ve öğretmenlerin verdikleri yanıtlardan elde edilen bulgular Tablo 2'de verilmiştir.

Tablo2.

Fen Eğitiminin Başlaması Gereken Döneme İlişkin Öğretmen Görüşleri

\begin{tabular}{llcc}
\hline Tema & Kod & f & \% \\
\hline \multirow{3}{*}{ Fen Eğitiminin Başlaması Gereken Dönem } & Okul öncesi dönemde başlamalı & 68 & 97.2 \\
& Ailede başlamalı & 1 & 1.4 \\
& İlköğretimde başlamalı & 1 & 1.4 \\
\hline
\end{tabular}

Araştırmaya katılan okul öncesi öğretmenlerinin tamamına yakını (\%97.2) fen eğitiminin okul öncesi dönemde, birer öğretmen ise ailede (\%1.4) ve ilköğretimde (\%1.4) başlaması gerektiği şeklinde düşüncelerini belirtmişlerdir. Bu temaya ilişkin bazı örnek öğretmen görüşleri aşağıda belirtilmiştir:

Ö6: "Çocuklar okul öncesi dönemde araştırma ve incelemeye daha merakl oluyorlar. Bu yaşlarda verilen ĕ̆itim gelecek yaşantılarında onlara rehberlik edeceğinden okul öncesinde fen ĕgitimi kesinlikle verilmelidir."

Ö24: "Okul öncesi dönemde çok önemli ama daha öncesinde yani ailede fen ĕgitimine başlanmall. Böylece çocuk okul öncesinde kavramları daha iyi öğrenir."

Ö30: "Fen eğitimi okul öncesinde çok gereklidir. Ancak kavramlar soyut olduğu için anlamada zorlanıyorlar. Ilköğretimde verilmesi gerekir.”

Öğretmenlere üniversite öğrenimleri esnasında verilen Fen Eğitimi dersinin yeterliliğine ilişkin görüşlerini belirlemek için "Lisans öğreniminiz esnasında verilen Fen Eğitimi dersinin yeterliliği konusundaki düşüncelerinizi açıklar mısınız?” sorusu sorulmuş ve öğretmenlerin verdikleri yanıtlardan elde edilen bulgular Tablo 3'te verilmiştir.

Tablo 3.

Üniversitede Verilen Fen Eğitimi Dersinin Yeterliliğine İlişkin Öğretmen Görüşleri

\begin{tabular}{llcc}
\hline Tema & Kod & f & \% \\
\hline \multirow{3}{*}{ Lisans Fen Eğitimi Dersinin Yeterliliği } & Yeterli değil & 37 & 52.9 \\
& Yeterli & 18 & 25.7 \\
& Kismen yeterli & 15 & 21.4 \\
\hline
\end{tabular}

Lisans öğrenimi esnasında alınan Fen Eğitimi dersinin yeterliliği konusunda öğretmenlerin çoğunluğu (\%52.9) bu dersin yeterli olmadığını; teorik olarak verildiği, uygulamaların olmadığı, daha fazla ders olması gerektiği vb. gerekçelerle dile getirmişlerdir. Öğretmenlerin \%25.7'si bu dersin yeterli olduğunu, \%21.4'ü ise kısmen yeterli olduğunu belirtmişlerdir. Bu temaya ilişkin bazı örnek öğretmen görüşleri aşağıda belirtilmiştir:

Ö17: "Lisans dönemindeki dersi yeterli bulmuyorum. Tamamen teorikti. Lisans döneminde uygulama imkânının daha fazla olması gerekir diye düşünüyorum. Lisans ĕgitiminde fen ĕgitimi derslerine daha çok ăgırlık verilerek, bu konuda kaliteli öğretmenler yetiştirilmeli bence."

Ö67: "Lisans eğitiminde verilen fen eğitimi dersi yeterliydi. Bir de benim okuduğum fakülte çık iyiydi bence. Fen etkinlikleri konusunda yeteri kadar bilgi sahibi olduğumu düşünüyorum. Bu eğitimi almamış olsaydım haftada en az birkaç defa fen etkinlikleri yapamazdim."

Ö30: "Üniversitede aldı̆̆ımız Fen Ĕ̈itimi bana göre orta seviyede yeterli idi denilebilir. Kısmen yeterli olduğunu düşünüyorum. Ama keşke daha çok çocuklara yönelik uygulamalı etkinlikler içerseydi daha iyi olurdu. Sürekli gelişen bir alan, ögretmenin de kendini geliştirmesi gerek."

Okul öncesinde fen etkinliklerine ilişkin olarak öğretmenlere rehber olacak kitaplar hakkındaki öğretmen görüşlerini belirlemek için "Okul öncesinde fen eğitimi, fen etkinlikleri vb. konularda yazılmış ve öğretmenlere rehber olabilecek kitaplar hakkındaki görüşlerinizi açıklar mısınız?” sorusu sorulmuş ve öğretmenlerin verdikleri yanıtlardan elde edilen bulgular Tablo 4 'te verilmiştir. 
Tablo 4.

Okul Öncesi Dönem Fen Eğitimi/Etkinlikleri Kitaplarına İlişkin Öğretmen Görüşleri

\begin{tabular}{lllc}
\hline Tema & Kod & f & \% \\
\hline & Yeterli & 33 & 47.1 \\
Fen Eğitimi ve Etkinliklerine Yönelik Kitaplar & Yetersiz & 26 & 37.1 \\
& Kismen yeterli & 10 & 14.3 \\
& Fikrim yok & 1 & 1.5 \\
\hline
\end{tabular}

Fen eğitimi ve fen etkinlikleri ilgili olan kaynak kitapların yeterlilik durumuna ilişkin olarak okul öncesi öğretmenlerinin çoğunluğu (\%47.1) mevcut kitapların yeterli içeriklere sahip olduğunu dile getirmiştir. Katılımcıların yarıya yakın kısmı (\%37.1) yetersiz olduğunu; kitapların içeriklerinin yetersiz ve birbirine benzer olduğu, uygulama örnekli kitapların olmadığı gibi gerekçelerle dile getirmişlerdir. Öğretmenlerin \%14.3’ü kitapların kısmen yeterli olduğunu ifade ederken bir öğretmen ise bu konuda fikrim yok şeklinde görüşünü belirtmiştir. Bu temaya ilişkin bazı örnek öğretmen görüşleri aşağıda belirtilmiştir:

Ö15: “Tamamen fen eğitimi üzerine olan veya fen etkinliklerini içeren kitapları çok yararlı buluyorum. Bence yararlanmak isteyen ögretmen için gayet yeterli. Fen eğitimi ve etkinlikleri ilgili yazılmış kitaplar her ögretmende mutlaka bulunmasi gereken kitaplar."

Ö43: "Fen ile ilgili kitaplar daha çok akademisyenler tarafindan akademik bir dille yazılan ve çoğunlukla teorik olan kitaplar. Etkinlik örnekleri ile proje örnekleri ile desteklense iyi olur aslında. Bir de kitaplar sanki üç aşağı beş yukarl birbiri ile benzer içeriklere sahipler. Yani ben bu yüzden bu kitaplarl yeterli bulmuyorum."

48: "Yani kısmen yeterli denilebilir. Piyasada zaten çok kitap yok bu konuda. Çoğunda etkinlik örnekleri bile yok. Olanlarda da etkinlikler ya çok basit ya da zor. Çocukların seviyesine uygun kitap bulmak zor.”

Öğretmenlerin fen etkinliklerini planlama ve uygulama konusundaki yeterliliklerine ilişkin görüşlerini belirlemek için "Fen etkinliklerini planlama ve uygulama konusunda yeterlilik durumunuzu nasıl tanımlarsınız?" sorusu sorulmuş ve öğretmenlerin verdikleri yanıtlardan elde edilen bulgular Tablo 5 'te verilmiştir.

Tablo 5.

Öğretmenlerin Fen Etkinliklerini Planlama ve Uygulama Konusundaki Yeterliliklerine İlişkin Görüşleri

\begin{tabular}{llcc}
\hline Tema & Kod & f & \% \\
\hline \multirow{2}{*}{ Fen Etkinliklerini Planlama ve Uygulamada } & Yeterli buluyorum & 40 & 57.1 \\
Öğretmenin Yeterliliği & Kismen yeterli buluyorum & 22 & 31.4 \\
& Yetersiz buluyorum & 8 & 11.5 \\
\hline
\end{tabular}

Öğretmenlerin çoğunluğu (\%57.1) fen etkinliklerini planlama ve uygulama konusunda kendilerini yeterli olarak tanımlamışlardır. Öğretmenlerin \%31.4'ü bu konuda kendisini kısmen yeterli olarak tanımlarken \%11.5'i ise yetersiz olarak tanımlamıştır. Kısmen yeterli ve yetersiz olarak tanımlayan öğretmenler bu durumun gerekçeleri arasında yeterli bilgi ve becerilerinin olmaması, materyal eksikliği, hizmet içi kurs eksikliği gibi nedenler dile getirmişlerdir. Bu temaya ilişkin bazı örnek öğretmen görüşleri aşağıda belirtilmiştir:

Ö31: "Fen etkinliklerini planlama ve uygulamada kendimi oldukça yeterli görüyorum. Çocuklara yaptı̆̆ım fen etkinlikleri ile bu konuda yardımcı olmaya, fen doğa kavramlarının daha fazla kalıcı olmasına gayret ediyorum. Fen etkinlikleri planlama ve uygulama konusunda herhangi bir desteğe ihtiyacım yok."

Ö15: "Klsmen yeterli hissediyorum. Yani şöyle izah edebilirim: Fen etkinliklerini uygularken bunları çocukların yaşlarına uyarlamakta bayağı zorlanıyorum. Bunun yanında sınıfta birçok eksiklik de var. Materyaller konusunda desteğe çok ihtiyacım var."

Ö51: "Yetersiz olduğumu söyleyebilirim. Aslında lisans döneminde Fen Ĕ̈itimi ve benzeri derslerde de etkinlik planlama ve uygulama noktasında çok sıkıntı yaşamıştık. Hep yetersizlikler vardı orda da. Milli Eğitimde de ne bir destek ne bir hizmet içi kurs yok maalesef. Kurslar verilebilir. Etkinlik planı veya bilgi edineceğim bir şey yok bu yüzden yeterli hissetmiyorum."

Öğretmenlerin kendi sınıflarında fen etkinliklerini uygulama konusundaki görüşlerini belirlemek için "Sınıfınızda fen etkinliklerini uygulama konusundaki düşüncelerinizi açıklar mısınız?" sorusu sorulmuş ve öğretmenlerin verdikleri yanıtlardan elde edilen bulgular Tablo 6'da verilmiştir.

Tablo 6.

Sinıfta Fen Etkinliklerini Uygulama Konusuna İlişkin Öğretmen Görüşleri

\begin{tabular}{llcc}
\hline Tema & Kod & f & \% \\
\hline \multirow{3}{*}{ Sinıfta Fen Etkinliklerini Uygulama } & Düzenli olarak yapıyor & 36 & 51.4 \\
& Ara sira yapıyor & 28 & 40.0 \\
& Planda varsa yapıyor & 6 & 8.6 \\
\hline
\end{tabular}

Sınıflarında fen etkinliklerini uygulamaya ilișkin olarak okul öncesi öğretmenlerinin çoğunluğu (\%51.4) her hafta düzenli olarak bu etkinlikleri uyguladıklarını belirtmiştir. \%40’1 ise ara sıra uygulayabildiklerini ve bu 
durumu da materyal eksikliği, fiziki imkânların yetersizliği, etkinlik yapma konusunda yetersizlik gibi gerekçelerle dile getirmişlerdir. 6 öğretmen ise hazır planlara göre ders yaptı̆̆ını ve planda var ise uyguladığını dile getirmiştir. $\mathrm{Bu}$ temaya ilişkin bazı örnek öğretmen görüşleri aşağıda belirtilmiştir:

Ö35: "Düzenli olarak her hafta fen etkinlikleri yapıyorum. Çocukların oldukça ilgisini, dikkatini çeken ve aktif olarak katılım sağladıkları etkinlikler oluyor. Bir de çocuklar yaparak yaşayarak öğrendikleri için çok önemsiyorum."

Ö6: "Materyal sıkıntısindan, fiziki imkânlardan dolayı uygulamalı olarak pek yapamıyoruz. Yine de ara sıra uygulamaya çalışlyoruz. Bazen de günlük etkinlikler sirasinda fenle ilgili bir kavram geçerse çocuklarla sohbet ederek de olsa yer vermeye çallşlyorum."

Ö51: "Düzenli olarak yaptı̆̆ım söylenemez. Ben derslerim için hazır planlar kullanlyorum. Ĕger planda yer verilmişse ben de elimden geldiğince yapmaya çalışlyorum. Çoğunlukla da deney gibi etkinlikler oluyor."

Öğretmenlerin kendi sınıflarında bulunan fen merkezindeki materyallerin yeterliliğine ilişkin görüşlerini belirlemek için "Fen etkinliklerini yapmak için sınıfınızdaki fen merkezinde bulunan materyallerin yeterliliği konusundaki düşüncelerinizi açıklar mısınız?” sorusu sorulmuş ve öğretmenlerin verdikleri yanıtlardan elde edilen bulgular Tablo 6'da verilmiştir.

Tablo 6.

Fen Merkezlerinde Yer Alan Materyallerin Yeterliliğine İlişsin Öğretmen Görüssleri

\begin{tabular}{llcc}
\hline Tema & Kod & f & \% \\
\hline \multirow{2}{*}{ Fen Merkezlerinde Bulunan Materyaller } & Yetersiz & 57 & 81.4 \\
& Yeterli & 13 & 18.6 \\
\hline
\end{tabular}

Öğretmenlerin büyük çoğunluğu (\%81.4) çocukların merak duygusu ve öğrenme arzusunu uyarmayı ve çocukların yaşadıkları dünya hakkında yeni şeyler öğrenmelerini desteklemeyi amaçlayan fen merkezinde bulunan materyallerin yetersiz olduğunu dile getirmişlerdir. Bu yetersizliği aşmak için de çoğunlukla kendi imkânları ile veya velilerden destek aldıklarını ifade etmişleridir. Öğretmenlerin sadece \%18.6'sı sınıflarındaki fen merkezlerinde yeterli düzeyde materyale sahip olduğunu belirtmiştir. Bu temaya ilişkin bazı örnek öğretmen görüşleri aşağıda belirtilmiştir:

Ö19: "Sinffimdaki fen merkezinde yeterli materyallere sahip değiliz. Kendi imkânlarımızla köşemizi doldurmaya çalışyoruz. Bazen ailelerden destek istiyoruz. Aslında tüm okullarda benzer slkıntı var."

Ö36: "Çalışı̆ğm okul şanslı bir okul. Okulumuz materyal ve donanım bakımından yeterli donanıma sahip. Sinıfimda da tüm merkezlerde yeterli materyaller mevcut, bir sıkıntı çekmiyorum."

Sınıfta fen etkinlikleri yaparken gerekli olan materyalleri geliştirip geliştirememe durumlarına ilişkin olarak öğretmenlere "Fen etkinliklerinde kullanabilecek materyalleri geliştirebilme ilgili durumunuzu açıklar mısınız?" sorusu sorulmuş ve öğretmenlerin verdikleri yanıtlardan elde edilen bulgular Tablo 7'de verilmiştir.

Tablo 7.

Fen Etkinliklerinde Kullanılan Materyallerin Geliștirilmesine İlișkin Öğretmen Görüssleri

\begin{tabular}{llcc}
\hline Tema & Kod & f & \% \\
\hline Öğretmenlerin Fen Materyalleri Geliştirme & Geliştirebiliyorum & 56 & 80.0 \\
Durumları & Geliştiremiyorum & 14 & 20.0 \\
\hline
\end{tabular}

Fen etkinlikleri yaparken ihtiyaç duyulan materyallerin geliștirilmesi ile ilgili olarak okul öncesi öğretmenlerin büyük bir çoğunluğu (\%80) sınıflarında uyguladıkları fen etkinlikleri için materyalleri geliştirebildiklerini dile getirirken öğretmenlerin \%20'si materyal geliştiremediklerini ve desteğe ihtiyaçları olduğunu ifade etmişlerdir. Bu temaya ilişkin bazı örnek öğretmen görüşleri aşağıda belirtilmiştir:

Ö44: "Evet geliştiriyorum. Mesela derslerimizde katı atıklardan çok çeşitli materyaller oluşturup kullaniyorum. Doğada bulunan toprak, taş, yaprak gibi ürünleri kullanarak deney gibi faaliyetlerde kullaniyorum."

Ö39: "Aslinda bu biraz beceri isteyen bir durum. Maalesef bu konuda çok yetenekli değilim. Okullartn imkânları da yeterli olmadı̆̆ından gerekli materyalleri geliştiremiyoruz. Bir de üniversite ylllarımda verilen eğitimin de yetersiz olduğınu düşü̈üyorum, bu yüzden bu konuda kursların gerekli olduğınu düşünüyorum. Materyalleri geliş̧tirme konusunda desteğe ihtiyacım var."

Öğretmenlerin fen eğitimi sürecinde fen etkinlikleri gerçekleştirirken kullandıkları yöntem ve tekniklere ilişkin görüşlerini belirlemek için "Fen etkinliklerini yaparken kullandığınız yöntem ve teknikler nelerdir?" sorusu sorulmuş ve öğretmenlerin verdikleri yanıtlardan elde edilen bulgular Tablo 8'de verilmiş̧ir. 
Tablo 8.

Fen Etkinliklerinde Kullanılan Yöntem ve Tekniklere İlişkin Öğretmen Görüşleri

\begin{tabular}{llll}
\hline Tema & Kod & f & \% \\
\hline & Deney & 36 & 14.9 \\
& Soru Cevap & 33 & 13.7 \\
& İşbirlikli Öğrenme & 32 & 13.3 \\
& Drama & 28 & 11.6 \\
Fen Etkinliklerinde Kullanılan Yöntem ve & Gezi Gözlem & 27 & 11.2 \\
Teknikler & Proje & 26 & 10.8 \\
& Gösterip Yaptırma & 18 & 7.5 \\
& Kavram Haritaları & 18 & 7.5 \\
& Tartışma & 16 & 6.6 \\
& Anlatım & 5 & 2.1 \\
& Beyin Firtınası & 2 & 0.8 \\
\hline
\end{tabular}

Fen etkinliklerini yaparken kullanılan öğretim yöntem ve teknikleriyle ilgili olarak öğretmenlerin en fazla deney (\%14.9), soru cevap (\%13.7), işbirlikli öğrenme (\%13.3), drama (\%11.6), gezi gözlem (\%11.2) ve proje (\%10.8) gibi yöntem ve teknikleri kullandıkları belirlenmiştir. Bununla birlikte gösterip yaptırma, kavram haritaları, tartışma, anlatım ve beyin firtınası gibi yöntem ve tekniklerin de kullanıldı̆̆ı bulunmuştur. Bu temaya ilişkin bazı örnek öğretmen görüşleri aşağıda belirtilmiştir:

Ö70: “Hemen hemen tüm öğretim yöntemlerini, tekniklerini kullanmaya çalışıyorum ama en fazla deney, gösterip yaptırma, soru-cevap, tartışma, drama, proje, işbirlikli grup çalışmaları, koşullar uygun ise gezi gözlem gibi yerine göre kullaniyorum."

Ö37: "Neredeyse hepsini kullanıyorum ama genel olarak kavram haritaları, gözlem, grup çalışmaları, soru cevap, anlatım, tartışma vb. kullanıyorum."

Ö30: "Beyin firtınası, proje çalışmaları, gözlem, kavram haritaları, soru-cevap, drama, oyun gibi yöntemleri daha çok kullanıyorum."

Öğretmenlerin fen etkinliklerini gerçekleştirdikten sonra değerlendirme sürecinde nelere dikkat etiğine ilişkin görüşlerini belirlemek için "Fen etkinlikleri sonunda değerlendirme yaparken hangi noktalara dikkat ediyorsunuz? Açıklar mısınız?” sorusu sorulmuş ve öğretmenlerin verdikleri yanıtlardan elde edilen bulgular Tablo 9'da verilmiştir.

Tablo 9.

Fen Etkinliklerinin Değerlendirilmesinde Dikkat Edilen Noktalara İlişkin Öğretmen Görüşleri

\begin{tabular}{llll}
\hline Tema & Kod & f & $\%$ \\
\hline & Çocukların öğrenmesine & 22 & 23.9 \\
& Çocukların sonuç çıkartabilmesi & 20 & 21.7 \\
Değerlendirme Sürecinde Dikkat Edilen & Çocukların aktif katılımı & 17 & 18.5 \\
Hususlar & Çocukların ilgisini çekme & 7 & 7.6 \\
& Bilimsel süreç becerilerinin gelişimi & 7 & 7.6 \\
& Kazanım göstergelere uygunluk & 4 & 4.3 \\
& Çocukların merakını artırma & 4 & 4.3 \\
& Çocukların dikkatini çekme & 3 & 3.3 \\
& Uygulanabilirlik & 3 & 3.3 \\
& Çocukların seviyesine uygunluk & 3 & 3.3 \\
& Kavram yanılgılarını düzeltme & 1 & 1.1 \\
\hline
\end{tabular}

Öğretmenlerden yapmış oldukları fen etkinliklerinin değerlendirmelerini yaparken nelere dikkat ettiklerine ilişkin olarak öğretmenlerin çoğunlukla çocukların öğrenip öğrenmediklerine (\%23.9), etkinlikler sonunda çocukların sonuç çıkarıp çıkaramadıklarına (\%21.7), çocukların etkinliklere aktif katılımlarına (\%18.5) dikkat ettikleri belirlenmiştir. Bununla birlikte öğretmenlerin etkinliklerin değerlendirmesinde çocukların ilgisini çekmeye, bilimsel süreç becerilerinin gelişimine, kazanım ve göstergelere, çocukların merakını artırmaya, dikkatini çekmeye ve seviyelerine uygunluğuna, kavram yanılgılarını düzeltmeye ve günlük yaşamla ilişkilendirmeye de dikkat ettikleri şeklinde cevaplar da alınmıştır. Bu temaya ilişsin bazı örnek öğretmen görüşleri aşağıda belirtilmiştir:

Ö6: "Fen etkinliklerinden sonra değerlendirme yaparken öncelikle çocukların öğrenip öğrenmediğine, o etkinliğin kazanım ve göstergelerine ulaşıp ulaşmadı̆̆ına, çocukların katılımına ve etkinliğin yeterli düzeyde ilgi çekici olmasina $v b$. dikkat ederim." 
Ö29: “Öğrencilerin sonuca kendi ulaşmalarını ve problemlere çözüm üretmelerine dikkat ediyorum. Bilimsel süreç becerilerine katkı sağlamasına dikkat ediyorum. Yapılan etkinliğin çocukların dikkatini çekmesine, çocukların etkinliğe ilgi duymasına dikkat ediyorum."

Ö50: "Çocuklara kazandırdıkları, çocukların seviyesine uygunluğu, ilgilerini çekip çekmediği ve dikkatlerini çekip çekmediği gibi hususlara dikkat ederim."

\section{SONUÇ VE TARTIŞMA}

$\mathrm{Bu}$ araştırmada okul öncesinde fen eğitimine yönelik olarak öğretmen görüşlerinin ortaya konulması amaçlanmıştır. Çalışmanın amacı doğrultusunda nitel araştırma yöntemlerinden tarama çalışması yapılmış ve öğretmenlerin görüşleri yarı yapılandırılmış sorularla ortaya çıkartılmaya çalışılmıştır.

Okul öncesi dönemde çocukların bilimsel süreç becerilerini kazanabilmesi ve matematik ve fen eğitimine yönelik kavramların kazanılabilmesi için bu dönemde verilen fen etkinliklerinin önemi yadsınamaz (Akerson, Buck, Donnely, Nargund-Joshi, ve Weiland, 2011; Kamay ve Kaşker, 2006). Ancak okul öncesi dönemde fen eğitimi, uygulayıcı öğretmenler tarafından daha az zaman ayırdıkları düşünülmektedir. Bu durumun öğretmenlerin sınıf içerisindeki materyal eksikliği ve fen öğretimi konusunda kendilerini yetersiz görmelerinden kaynaklandığı bilinmektedir (Conezio ve French, 2002;). Benzer olarak Worth (2010) yapmış olduğu çalışmada okul öncesi öğretmelerinin daha çok çocukların sosyal duygusal, fiziksel ve dil alanlarında gelişimlerini desteklediklerini belirtmiştir. Buradan yola çıkarak Amerikan Ulusal Araştırma Merkezi (National Research Council) (2012) okul öncesi öğretmenlerinin, çocuklara bu dönemde matematik, fen (bilim), teknoloji ve mühendislik alanlarında gelişimlerini desteklemelerine yönelik olarak amaçlar oluşturmuş ve öğretmenlerin erken yaşlarda çocuklara düzenli olarak fen ve matematik alanlarında etkinliklere yer vermelerini belirtmiştir. Benzer olarak Türk Milli Eğitim Bakanlığı (MEB, 2016) tarafından çocuk gelişimi ve eğitimi üzerine yayınlanan Fen ve Matematik Etkinlikleri modülün de benzer olarak fen eğitiminin öncelikle ailede başlaması gerektiğgini belirtmiş ve fen eğitiminin okul öncesi dönemdekini vurgulamıştır. Bu çalışmada araştırmaya katılan öğretmenlerin çoğunluğunun fen eğitiminin okul öncesi dönemde verilmesi gerektiği düşüncesinde olduğu bulunmuştur. Bu durum öğretmenlerin okul öncesinde fen eğitiminin öneminin farkında olduklarını ancak etkinliklerin uygulanması noktasında farklı sebeplerin olabileceğini göstermektedir.

Geleneksel fen öğretimi anlayışından uzaklaşarak, okul öncesi çocukları feni öğrenirken ve uygularken gelecek için zevkli öğrenme ortamlarını geliştirmek, okul öncesi öğretmenlerinin en önemli görevlerinden biridir (Şahin, 1998; Üstünoğlu, 1990). Etkinlikler uygulanırken öğretmenin fen eğitimine karşı tutumu ve uygulamaya yönelik yeterliliği kadar sınıf içerisinde yeterli materyallerin bulunmasının da bu uygulamaların yapılabilmesi için önemli olduğu bilinmektedir (Kıldan ve Pektaş, 2009; Karamustafaoğlu ve Kandaz, 2006; Saçkes, 2014; Worth, 2010). Öğretmen, çocukların bilgiye kendi kendilerine yaparak-yaşayarak ulaşabilecekleri zengin uyarıcılarla dolu öğrenme ortamlarını, onların ilgi ve yeteneklerini göz önüne alarak düzenlemekle ve bu ortamlar içerisinde yeni bilgileri öğrenmelerine, eksik olanları tamamlamalarına, yanlış olanları düzeltmelerine yardımcı olmakla sorumludur (Demiriz ve Ulutaş, 2001). Ancak bu merkezlerde bulunan materyallerin her zaman çocukların bilimsel süreç becerilerini destekleyecek nitelikte ve nicelikte olmayabilmektedir (Kıldan ve Pektaş, 2009; Karamustafaoğlu ve Kandaz, 2006). Çınar (2013) yaptığı çalışmada okul öncesi öğretmenlerinin fen etkinliklerini uygulamalarında sınıf içi materyal eksikliği, fen konu alan bilgisi yetersizliği, velilerin ve idarecilerin bu konulardaki tutumunun sınıf içerisindeki fen etkinliklerinin uygulanmasında önemli faktörler olduğunu saptamıştır. Aynı şekilde Saçkes (2014), sınıf içerisinde bulunan materyallerin yeterlilik durumunun öğretmenlerin fen öğretimi sıklığını etkilediğini belirtmiştir. Benzer olarak bu çalışmada da öğretmenlerin sınıf içerisinde yeteri kadar materyale sahip olmadıkları ve bunların veliler, okul idaresi ve MEB tarafından desteklenmesi gerektiğini belirtmişlerdir. Ayrıca araştırmaya katılan okul öncesi öğretmenlerinin çoğunluğunun sınıf içi materyal ihtiyacının kendilerinin karşıladıklarını ancak yine de bu konuda daha fazla fen etkinlikleri yapabilmeleri için materyalleri geliştirme konusunda farklı destek eğitimlerine ihtiyaç duyduklarını belirtmişlerdir.

Fen konuları çocuğun doğasına en yakın konular olup, okul öncesi dönemde çocuğun amacı çevresinde olup bitenleri anlamaktır. Çocuğun merak ettiği konulara getirilen açıklamalar ve sorduğu sorulara verilen yanıtlar çocuğun anlayacağı dilde olursa, çocuğun yakın çevresine ve öğrenmeye karşı ilgisi daha da artmaktadır. Ancak çocuğun bu ilgisi zaman geçtikçe azalmaktadır. Bu ilgi azalması, fen eğitimi programlarının çocuğun gerçek ilgi ve ihtiyaçlarına dayanmamasına, konuların gerçek hayattan kopuk bir şekilde işlenmesine bağlıdır (Gürdal, Şahin ve Çağlar, 2001 ). Bu konuda lisans düzeyinde verilen yeterli düzeydeki fen eğitiminin okul öncesi öğretmenlerinin sınıfta daha fazla fen eğitimine yer vermesiyle doğrudan ilişkili olduğu düşünülmektedir (Saçkes, 2014). Bu süreçte alınan hem teorik hem de uygulamalı eğitimlerle öğretmen adayları fen eğitimi becerilerini geliştirmektedirler. Ancak bu şekilde öğretmenlerin bu konuda yeterli düzeyde uygulamalar yapması ileriki yıllarda fen öğretimlerine daha fazla yardımcı olacak ve fen öğretimi öz yeterlilik inançları gelişecektir (Carrier, 
2009; Plourde, 2002). Bu çalışmada okul öncesi öğretmenleri lisans düzeyinde almış oldukları derslerin yeterli olmadığını vurgulamış ve bu konuda daha fazla teorik ve uygulamalı derslere yer verilmesi gerektiğini dile getirmişlerdir. Bu konuda öğretmenlerin kendilerine verilen derslerin yeteli olmadığını düşünmeleri, eğitim sürecinde fen etkinliklerine verdiği zamanı da etkilediği tespit edilmiştir.

Okul öncesi dönemde fen etkinliklerinin önemi yadsınamaz. Ancak öğretmenlerin kendilerini bu konuda yetersiz görmeleri, pedagojik alan bilgilerinin yetersizliği eğitimlerinde fen etkinliklerine daha az zaman ayırmalarına sebep olmaktadır (Tu, 2006; Saçkes, 2014; Kallery ve Psillos, 2001; Usta ve Ültay, 2017). Usta ve Ültay (2017) yapmış oldukları çalışmada öğretmenlerin çoğunluğunun haftada 2-3 kez fen etkinliklerine yer verdiklerini belirtmişlerdir. Bu çalışmada da katılımcıların çoğunluğunun düzenli olarak ve haftada birkaç kez fen etkinliklerine yer verdikleri saptanmıştır. Bu durumun literatürde de yer verildiği gibi öğretmenlerin öz yeterlik algılarından, fiziki imkânların yetersizliğinden ve merkezlerin materyal bakımından buna uygun olup olmamasından kaynaklandığı düşünülmektedir.

Ayvac1, Devecioğlu ve Yiğit (2002), okul öncesi öğretmenlerinin fen etkinliklerini istenen nitelikte planlama ve yürütme becerisine sahip olmadıklarını, orijinal materyal geliştirmediklerini ve etkinlikleri uygularken kullanılacak etkili öğretim yöntemlerinden "soru-cevap, gösterip yaptırma" dışındaki diğer yöntemlerden "oyun ve drama vb." haberdar olmadıklarını ve kullanmadıklarını belirtmişlerdir. Bu konuda benzer olarak Karaer ve Kösterellioğlu (2005) yapmış oldukları çalı̧̧mada da benzer sonuçlar ortaya koymuş ve okul öncesi öğretmenlerin almış oldukları eğitimin yeterli olmadığını dile getirerek hizmet içi eğitimlerle bu öğretmenlerin desteklenmesi gerektiğini vurgulamıştır. Bununla ilgili olarak Ayvacı, Devecioğlu ve Yiğit (2002) yapmış oldukları çalışmada öğretmenlerin materyallerin yeterli olmadı̆̆ı için desteğe ihtiyaç duyduklarını ayrıca, eğitimleri süresince geleneksel eğitim yöntemlerini kullandıklarından dolayı kendilerini geliştirmek için çaba sarf etmemeleri fen ve doğa eğitimlerine olan ilgilerini etkilediğini belirtmiştir. Usta ve Ültay (2017) öğretmenlerin materyal yönünden eksik kalmasından dolayı üniversitelerle işbirliği yapılmasını önermiştir. Ayrıca araştırmacılar öğretmenlerin fen eğitimine daha az zaman ayırmalarından dolayı bu konudaki eksiklerinin hizmet içi eğitimlerle desteklenmesi gerektiğini vurgulamışlardır (Ayvacı vd., 2002; Doğan ve Simsar, 2018; Usta ve Ültay, 2017). Bu çalışmada da öğretmenlerin çoğunluğunun fen ve doğa etkinliklerinin planlanması ve uygulanması konusunda hem yeterli materyalin olmaması hem de bu konuda geliştirici hizmet içi eğitimler talep etmesi, onların fen eğitimi noktasında eksik kaldığını göstermektedir.

Okul öncesi dönemde fen etkinlikleri yaparken öğretmenler daha çok anlatma, dramatizasyon, model kullanma ve deney yapma gibi teknikleri kullandığı belirtilmiştir (Karamustafaoğlu ve Kandaz, 2006). Bir başka çalışmada ise öğretmenlerin soru-cevap, açıklama, demonstrasyon, oyun ve gözlem gibi tekniklere daha fazla yer verirken, problem çözme, drama, şiir, dramatizasyon, bulmaca anoloji gibi tekniklere yer vermedikleri söylenmiştir (Parlakyıldız ve Aydın, 2004). Şahin (1996) yapmış olduğu çalışmada, okul öncesi öğretmenlerinin fen kavramlarının öğretiminde en çok deney yöntemini kullandıklarını, buna karşılık kavram haritaları ve anolojileri kullanmadıklarını belirtmiştir. Benzer bulgulara bu çalışmada da ulaşılırken katılımcıların en fazla deney, soru cevap ve işbirlikli ögrenme gibi yöntem ve tekniklere yer verirken en az ise beyin firtınası, anlatım ve tartışmaya yer verdikleri saptanmıştır.

Okul öncesi dönemde fen etkinlikleri uygulanılırken çeşitli materyallerden yararlanılmaktadır. Karamustafaoğlu ve Kandaz, (2006) yapmış oldukları çalışmada sınıf içerisinde en fazla kullanılan materyalin kuru-canlı bitkiler ve tartı aletleri olduğunu belirtmiştir. Sackes, Trundle ve Flevares (2009) yapmış oldukları çalışmada birçok çocuk kitaplarını incelemiş ve hayat bilimleri fen kavramlarına yönelik olarak çocuk kitaplarının olmasının okul öncesi öğretmenlerinin bu kavramları verirken kendilerini daha rahat hissedeceklerini belirtmiştir. Ayrıca araştırmacılar kitaplarla ilgili olarak görsellerinin ve mantıksal açıdan sorunlar olduğunu belirtmişlerdir. Başka bir çalışmada, Pringle ve Lamme (2005) öğretmenlerin çocuk kitapları seçerken yazarların ve çizerlerin fen eğitimi geçmişlerinin olup olmamasına dikkat etmeleri gerektiğini önermiştir. Bu çalışmada da öğretmenlerin okul öncesi dönemde fen etkinliklerine yönelik olarak hazırlanan kitapların yeterliliğini ancak kitapların birbirine benzer içeriklere sahip olduğunu ve uygulama örnekli kitapların yetersizliğini düşündükleri saptanmıştır. $\mathrm{Bu}$ durumun öğretmenlerin lisans düzeyinde almış oldukları fen eğitiminin yetersiz olmasından ve çoğunluğunun fen ve çevre alanlarına yönelik yayınları takip etmemesi, bu konudaki etkinliklere daha az katılmalarından kaynaklandığı düşünülmektedir.

Bununla birlikte okul öncesi eğitim programında (MEB, 2013) eğitim sürecinin değerlendirilmesine yönelik farklı yöntem ve tekniklerden bahsedilmiş; sürecin çocuk açısından, program açısından ve öğretmen açısından değerlendirilmesi gerektiği vurgulanmıştır. Bu çalışmada, öğretmenler yapmış oldukları fen etkinliklerinin değerlendirilmesini daha çok çocuğun konuyu öğrenebilmesi, sonuç çıkartabilmesi ve etkinliğe aktif ve ilgili bir şekilde katılımıyla olduğunu dile getirmişlerdir. Bu durumun olmasının temel sebebi, fen etkinliklerine daha az zaman ayrılmasından dolayı çocukların bu tür etkinliklere karşı ilgisi ve merakı da tam tersi 
yönde artmaktadır. Bundan dolayı öğretmen diğer etkinlik türleriyle verebilecekleri pek çok kavramı fen etkinlikleri yaparak da verebilmektedir. Bu yüzden fen etkinliklerinde sürecin değerlendirilmesi aşamasında en büyük ölçüt çocuğun ilgisini çekebilmesi olmalıdır.

\section{Uygulamaya Yönelik Öneriler}

\section{ÖNERILER}

Görüşmelerde öğretmenler materyal olarak daha çok fen ile ilgili kitapları kullandıklarını, fen köşelerindeki materyallerin yetersiz olduğu ve kendilerinin hazırlamadıklarını belirtmiş̧lerdir. Okul öncesi fen eğitiminin çocuğun fene karşı pozitif tutumla yetişmesinde ne kadar büyük öneme sahip olduğu düşünüldüğünde okul öncesi eğitim programında gerçekleştirilecek olan fen etkinliklerinin en etkili şekilde yürütülebilmesi için gerekli bilgi ve becerilerin okul öncesi öğretmenlerine kazandırılması gerekmektedir. Okul öncesi öğretmenlerinin bu becerileri kazanabilmesi için lisans düzeyinde okutulan materyal geliştirme derslerinin bir bölümünde fen etkinliklerinde kullanılabilecek materyallerin geliştirilmesine ve öğretmen adaylarının bu yöndeki becerilerinin oluşturulmasına yardımcı olunmalıdır.

Okul öncesi fen etkinlikleri uygulama sürecinde kullanılacak öğretim yöntem ve tekniklerinin öğretmen tarafından öğrencilerin ilgi ve ihtiyaçları doğrultusunda belirlenebilmesi ve etkili bir şekilde uygulanabilmesi gerekmektedir. Okul öncesi öğretmeni olarak görev yapan öğretmenlerin fen etkinliklerini planlaması, uygulaması ve değerlendirmelerine yönelik eksikliklerin giderilmesi amacıyla uzman kişilerin rehberliğinde hizmet içi eğitim kursları planlanmalı ve gerekli sıklıklarla uygulanmalıdır.

Öğretmenlerin fen etkinliklerin de çocukların ilgisini çekmek için farklı yöntemler denemeleri, etkinlikleri uygulama sürecinde çocuğun da aktif olarak katılmasıyla öğrendiklerini farklı durumlara aktarabilmelerine olanak sağlayacak değişik etkinliklere yer vermeleri amaçlarına ulaşmalarına katkı sağlayacaktır.

Çocuklar fen eğitimine yeni başladıklarında başarılı deneyimler ve olumlu hisler kazanılırsa ileriki fen ile ilgili deneyimlerinde başarılı olabileceklerdir aksi takdirde hayatlarının geri kalan kısmında çoğunlukla fen derslerinden sakınacaklardır (Simpson ve Oliver, 1990). Bu nedenle öğretmenler, çocukların fen konularında cesaretlenmelerine, keşifler ve deneyler yapabilmelerine olanak sağlayan ortamlar hazırlanmalı, bilgiler doğru ve onların gelişim düzeyine uygun bir şekilde verilmelidir.

\section{Yapılacak Araștırmalara Yönelik Öneriler}

$\mathrm{Bu}$ çalışmada okul öncesi öğretmenlerinin fen eğitimine ilişkin görüşleri, fen etkinliklerini planlama ve uygulamaları incelenmiştir. Daha sonraki çalışmalarda bu beceriler arasında eğitim durumu, yaş, kıdem yılı ve çalışma saatlerine göre bir farklılık olup olmadığı araştırılabilir.

Okul öncesi öğretmenlerinin fen etkinliklerini sadece planlama ve uygulama durumlarına odaklanılmıştır. Daha sonraki çalışmalarda değerlendirme becerileri açısından değişkenlere göre farklılık olup olmadığı araştırılabilir.

Fen etkinliğini planlama ve uygulama durumlarında sınıflarda fen köşelerinin olup olmaması, köşedeki materyallerin niteliği, okulun fiziksel koşulları gibi değişkenler arasında bir ilişkinin olup olmadığı araştırılabilir.

\section{KAYNAKÇA}

Akerson, V. L., Buck, G. A., Donnelly, L. A., Nargund-Joshi, V. and Weiland, I. S. (2011). The importance of teaching and learning nature of science in the early childhood years. Journal of Science Education and Technology, 20, 537-549. doi:10.1007/s10956-011-9312-5

Aktaş-Arnas, Y. (2002). Okul öncesi dönemde fen eğitiminin amaçları. Çocuk Gelişimi ve Eğitimi Dergisi, 1(67), 1-6.

Alisinanoğlu, F., Özbey, S. ve Kahveci, G. (2015). Okul öncesinde fen eğitimi (3. Baskı). Ankara: Pegem Akademi.

Aslan, O.,Şenel-Zor, T. ve Tamkavas-Cicim, E. (2015). Okul öncesi öğretmenlerinin fen eğitimine yönelik görüşlerinin ve hizmetiçi eğitim ihtiyaçlarının belirlenmesi. Uluslararası Sosyal Araştırmalar Dergisi, $8(40), 519-530$.

Ayvac1, H. Ş., Devecioğlu, Y. ve Yiğit, N. (2002, Eylül). Okul öncesi öğretmenlerinin fen ve doğa etkinliklerindeki yeterliliklerinin belirlenmesi. 5. Ulusal Fen Bilimleri ve Matematik Eğitimi Kongresi, Orta Doğu Teknik Üniversitesi, Ankara.

Bilaloğlu, R. G. (2014). Okul öncesi dönemde fen eğitimi ve etkinlik örnekleri. Aktaş-Arnas, Y. (Ed.). Okul Öncesi Eğitiminde Matematik ve Fen Etkinlikleri içinde (2. Baskı). Ankara: Vize Yayıncılık. 
Brenneman, K. (2011). Assessment for preschool science learning and learning environments. Early Childhood Research \& Practice, 13(1), 1-9.

Büyüköztürk, Ş., Çakmak, E. K., Akgün, Ö. E., Karadeniz, Ş. ve Demirel, F. (2017). Bilimsel araştırma yöntemleri. ( 23. Bask1). Ankara: Pegem Akademi.

Çamlıbel-Çakmak, Ö. (2012). Okul öncesi öğretmen adaylarının fen öğretime yönelik tutumları ile bazı fen kavramlarını anlama düzeyleri arasındaki ilişkinin incelenmesi. Türk Fen Eğitimi Dergisi, 9(3), 40-51.

Carrier, S. J. (2009). The effects of outdoor science lessons with elementary school students on preservice teachers' self-efficacy. Journal of Elementary Science Education, 21(2), 35-48.

Cho, H. S., Kim, J. ve Choi, D. H. (2003). Early childhood teachers' attitudes toward science teaching: a scale validation study. Educational Research Quarterly, 27(2), 33-42.

Çınar, S. (2013). Okul öncesi öğretmenlerin fen ve doğa konularının öğretiminde kullandıkları etkinliklerin belirlenmesi. Ĕgitim ve Öğretim Araştırmaları Dergisi, 2(1), 364-371.

Conezio, K. ve French, L. (2002). Science in the preschool classroom: capitalizing on children's fascination with the everyday world to foster language and literacy development. Young Children, 57(5), 12-18.

Dağlı, H. (2014). Okul öncesi ĕgitim kurumlarında uygulanan fen eğitiminin içeriği konusunda ögretmen görüşlerinin incelenmesi (Yayımlanmamış yüksek lisans tezi). Gazi Üniversitesi, Eğitim Bilimleri Enstitüsü, Ankara.

Davies, D. ve Howe, A. (2003). Teaching science and design and technology in the early years. London: David Fulton Publishers.

Demir, S. ve Şahin, F. (2015). Okul öncesi öğretmen adaylarının 5E yöntemini kullanarak deney yapma ile ilgili görüşleri. The Journal of Academic Social Science Studies, 35, 385-397.

Demiriz, S. ve Ulutaş, İ. (2001). Okul öncesi eğitim kurumlarındaki fen ve doğa etkinlikleri ile ilgili uygulamaların belirlenmesi. IV. Fen Bilimleri Ë̆itimi Kongresi, Ankara: MEB.

Doğan, Y. ve Simsar, A. (2018). Preschool teachers' views on science education, the methods they use, science activities, and the problems they face. International Journal of Progressive Education, 14(5), 57-76. doi: 10.29329/ijpe.2018.157.6

Ekinci-Vural, D. ve Hamurcu, H. (2008). Okul öncesi öğretmen adaylarının fen öğretimi dersine yönelik öz yeterlik inançları ve görüşleri. Ilköğretim Online, 7(2), 456-467.

Güler, D. S. ve Bıkmaz, F. H. (2002, Ağustos). Anasınıflarında fen etkinliklerinin gerçekleştirilmesine ilişkin öğretmen görüşleri. Eğitim Bilimleri ve Uygulamalarl, 1(2), 249-267.

Günay-Bilaloğlu, R., Aslan, D. ve Aktaş-Arnas, Y. (2008). Okul öncesi öğretmenlerinin fen etkinliklerine ilişkin bilgi düzeylerinin incelenmesi. Milli Ĕgitim Dergisi, 178, 88-104.

Güven, G., Ahi, B., Tan, S. ve Karabulut, R. (2013). Okul öncesi öğretmenlerinin kullandıkları öğretim yöntemleri hakkındaki görüşleri. Erciyes Üniversitesi Sosyal Bilimler Enstitüsü Dergisi, 34(1), 25-49.

Johnson, B. ve Christensen, L. (2008). Educational research: Quantitative, qualitative, andmixedapproaches. ThousandOaks, CA: Sage.

Kallery, M. (2004). Early years teachers' late concerns and perceived needs in science: An exploratory study. European Journal of Teacher Education, 27(2), 147-165.

Kallery, M. ve Psillos D. (2001). Pre-school teachers' content knowledge in science: Their understanding of elementary science concepts and of 1ssues raised by children's questions. International Journal of Early Years Education, 9(3), 165-179.

Kamay, P. O. ve Kaşker, Ş. Ö. (2006). Illk fen deneyimlerim. Ankara: SMG Yayıncılık.

Karasar, N. (2014). Bilimsel araştırma yöntemi. Ankara: Nobel Yayın Dağıtım.

Kıldan, O. ve Pektaş, M. (2009). Erken çocukluk döneminde fen ve doğa ile ilgili konuların öğretilmesinde okul öncesi öğretmenlerinin görüşlerinin belirlenmesi. Ahi Evran Üniversitesi Kırşehir Eğitim Fakültesi Dergisi, 10(1), 113-129.

Koballa, J. R. ve Crowley, F. E. (1985). The influences of attitude on science teaching and learning. School Science and Teaching, 20(4), 222-232.

McDewitt, T. M. ve Heikkinen, H. W. (1993). Evaluation of the preparation of teachers in science and mathematics: Assessment of preservice teachers' attitudes and beliefs. Science Education, 77(6), 593610.

Miles, M. B., Huberman, A. M. ve Saldana, J. (2014). Qualitative data analysis: A methods source book. Thousand Oaks: Sage.

Miles, M. B. and Huberman, A. M. (1994). An expanded source book: Qualitative data analysis (2nd Edition). Thousand Oaks: Sage. 
Millî Eğitim Bakanlığı (2013). Millî eğitim bakanlığı temel eğitim genel müdürlüğü okul öncesi eğitimi programı. Ankara: TTKB

Millî Eğitim Bakanlığı (MEB) (2016). Çocuk Gelişimi ve Eğitimi Fen ve Matematik Etkinlikleri Modülü. http://www.megep.meb.gov.tr/mte program modul/moduller/Fen\%20ve\%20Matematik\%20Etkinlikleri .pdf adresinden 26.05.2019 tarihinde erişilmiştir.

National Research Council. (2012). A framework for K-12 science education: Practices, crosscutting concepts, and core ideas. Committee on a Conceptual Framework for New K-12 Science Education Standards. Board on Science Education, Division of Behavioral and Social Sciences and Education. Washington, DC: The National Academies Press.

Okur-Akçay, N. (2016). Determining the views and adequacy of the preschool teachers related to science activities. Universal Journal of Educational Research, 4(4), 821-829.

Özbek, S. (2009). Okul öncesi ögrretmenlerinin fen eğitimine ilişkin görüşleri ve uygulamalarının incelenmesi (Yayımlanmamış yüksek lisans tezi). Çukurova Üniversitesi, Sosyal Bilimler Enstitüsü, Adana.

Özbey, S. (2006). Okul öncesi ĕgitim kurumlarında görev yapan ögretmenlerin fen etkinliklerine ilişkin yeterliliklerinin belirlenmesi. Yayımlanmamış yüksek lisans tezi. Gazi Üniversitesi, Eğitim Bilimleri Enstitüsü, Ankara.

Özen-Uyar, R. ve Ormancı, Ü. (2016). Türkiye'de okul öncesi dönem fen eğitimi araştırmalarında güncel eğilimler: Bir tematik analiz çalışması. Demirel, Ö., ve S. Dinçer, S. (Ed.). Eğitim Bilimlerinde Nitelik ve Yenilik Arayışı içinde. Ankara: Pegem Akademi.

Parlakyıldız, B. ve Aydın, F. (2004, Temmuz). Okul öncesi dönem fen eğitiminde fen ve doğa köşesinin kullanımına yönelik bir inceleme. XIII. Ulusal Eğitim Bilimleri Kurultayı, İnönü Üniversitesi, Malatya.

Plourde, L. A. (2002). The influence of student teaching on pre-service elementary teachers' science self-efficacy and outcome expectancy beliefs. Journal of Instructional Psychology, 29(4), 245-253.

Pringle, R. M. ve Lamme, L. L. (2005). Using picture story books to support young children's science learning. Reading Horizons, 46(1), 1-15.

Saçkes, M. (2014). How often do early childhood teachers teach science concepts? Determinants of the frequency of science teaching in kindergarten. European Early Childhood Education Research Journal, 22(2), 169184.

Saçkes, M., Trundle, K. C. and Flevares, L. M. (2009). Using children's literature to teach standard-based science concepts in early years. Early Childhood Education Journal, 36, 415-22.

Saçkes, M., Trundle, K. C., Bell, R. L. and O'Connell, A. A. (2011). The influence of early science experience in kindergarten on children's immediate and later science achievement: Evidence from the early childhood longitudinal study. Journal of Research in Science Teaching, 48(2), 217-235.

Şahin, F. (1996, Eylül). Okul öncesi öğretmenlerinin fen kavramlarının öğretiminde kullandıkları metotların tespiti. II. Ulusal Eğitim Sempozyumu, Marmara Üniversitesi, İstanbul.

Simpson, R. D. and Oliver, J. S. (1990).A summary of major influences on attitude toward and achievement in science among adolescent students. Science Education, 74(1), 1-18.

Tu, T. (2006). Preschool science environment: What is available in a preschool classroom? Early Childhood Education Journal, 33(4), 245-251.

Worth, K. (2010). Science in early childhood classrooms: Content and process. SEED: Collected Papers, adresinden http://ecrp.uiuc.edu/beyond/seed/worth.html erișilmiștir.

Yaşar, Ş. (1993). Okul öncesi eğitim öğrencilerinde fene yönelik duyuşsal özellikler. 9. Ya-Pa Okul öncesi Ĕ̌itim ve Yaygınlaştırılması Semineri, 140-142, Ankara. 


\title{
Investigation of Preschool Teachers' Views on Science Education Processes
}

\author{
Ahmet SIMSAR \\ Kilis 7 Arallk University, Muallim Rlfat Faculty of Education, Department of Preschool Education \\ e-mail: ahmetsimsarr@gmail.com \\ Yakup DOĞAN \\ Kilis 7 Aralık University, Muallim Rlfat Faculty of Education, Department of Preschool Education \\ e-mail: yakupdogan06@gmail.com
}

Citation: Simsar, A. and Doğan, Y.(2019). Investigation of preschool teachers' views on science education processes. E-Kafkas Journal of Educational Research, 6(2), 19-32.

\section{Extended Summary}

Preschool is the period in which knowledge and skills of children are laid as a foundation for life. Observations are made to find answers to questions about beings and events thus, the first concepts of science are formed (Alisinanoğlu, Özbey \& Kahveci, 2015; Güler \& B1kmaz, 2002). Therefore, it is an indisputable fact that systematic science education is an important necessity to start in early childhood education. In order for this educational process to proceed in a healthy way, it is very important that science education is given correctly and in accordance with the development of children. For this reason, the aim of science education in the preschool period is to provide children with basic information about the realization of basic phenomena and events related to nature. In addition, it is to gain affective and psychomotor skills to help them understand themselves and their environment. Therefore, the role of the early childhood teacher is not limited to planning science activities and providing relevant materials. In this study, it is aimed to examine in depth the views of preschool teachers who are active in the field related to preschool science education from a holistic perspective.

\section{Method}

This study is a phenomenological study examining preschool teachers' opinions about science education phenomenon. The study group consisted of 70 preschool teachers who worked in kindergarten and nursery classes affiliated with the Ministry of National Education in the city center of Kilis province, Turkey. The data was collected through an interview technique, which is frequently used in qualitative methodology (Johnson \& Christensen, 2008). The content analysis method was used for data analysis. The teachers' answers were transcribed on the computer and the qualitative data set was created. The recorded data were examined one-byone and coded by researchers to find themes and patterns (Miles, Huberman, \& Saldana, 2014). Frequency and percentage distributions of the codes obtained in the definition of preschool teachers' views about science education were calculated and given within tables.

\section{Conclusion and Suggestions}

As a result of this research, it was determined through the teachers' opinions, that science education should start in preschool. Science Education courses given in universities were insufficient, resource books related to science education were insufficient and teachers defined themselves as sufficient in planning and implementing science activities. It was determined that the majority of the teachers regularly carried out science activities in the classroom however, the materials in the science centers were insufficient. The teachers could develop the science materials they needed, as well as the methods and techniques such as; experiments questions and answers, group work, drama, trip observations, and projects. It was found that teachers pay more attention to learning and inducing the active participation of the children in the evaluation of science activities. In addition, the interviews revealed that the teachers self-reported mostly using books about science. The materials in the science corners were insufficient and they did not prepare them by themselves. Considering the importance of preschool science education to the positive attitude of children towards science, preschool teachers should acquire the necessary knowledge and skills in order to carry out the most effective science activities in the preschool education program. In order for preschool teachers to acquire these skills, some of the material development courses taught at undergraduate levels should be revised to develop materials that can be used in science activities and to build the skills of prospective teachers.

Moreover, teachers need to try different methods to improve children's' interest in science activities. This needs to include the active participation of children in the process of implementation of the activities that will enable them to transfer to different situations that will contribute to the achievement of their objectives. İn addition, teachersshould be provided with environments that allow children to be encouraged in science, to make discoveries and experiments, and the information should be given correctly and in accordance with their level of development. 